\title{
Determination of genetically modified rape and monitoring of its spread
}

\author{
R. Oblap, \\ candidate of diological sciences \\ State Enterprise "Ukrmetrteststandard"
}

The purpose. To complete methodical marching and to develop diagnostic test-system on the basis of method of polymerase chain reaction (PCR) in real time for determination of genetically modified rape (GM). Monitoring of spread of biotechnological rape in Ukraine. Methods. Molecular-genetic - extraction of DNA, PCR; biotechnological - development of test-system on the basis of PCR-method in real time (Real-Time PCR). Results. Screening testsystem is developed for determination of GM rape by PCRmethod in real time. The system allows to analyze both on regulatory elements (tNOS), and on structural genes (CP4 epsps, Pat, Bar, bay TE, bxn). By means of the developed system monitoring of spread of biotechnological rape in Ukraine is carried out, and availability of Roundup Ready ${ }^{\mathrm{TM}}$ rape in amounts exceeding $0,9 \%$ is shown. Conclusions. The gained results testify to necessity of supervisory control of agricultural raw, in particular seeds of rape, for the content of genetically modified organisms (GMO).

Key words: genetically modified organisms, polymerase chain reaction in real time, biotechnological rape.

Problem statement. Biotechnological agricultural crops are grown in global scale for the last 19 years. Areas for this crops has grown from 1,7 to 181,5 million hectares. In 2014 GM crops were planted in 28 world countries where more than a half of world population lives (60\%, 4 milliard of people). The most world-spread biotech crops are soybean (84,5 million hectares from total world plantings, $79 \%)$, cotton $(23,9$ million hectares, $70 \%)$ maize $(57,4$ million hectares, $32 \%)$ and rapeseed $(8,2$ million hectares, 24\%). Application of GM crops becomes the most spread agricultural technology nowadays. Economic benefit from biotech using in global scale amounted 133,3 milliard dollars from 1996 to 2013 and was gained by reduction of production expenses (30\%) and by significant increase of crop yield $(70 \%, 441,4$ million tones ) [1,2].

But despite existed benefits and promising perspectives for future, range of risks of GMO using safety exists. Such a risks are divided into three main groups: food risks which concern safety of GM using in food products; ecological which concern dangerous of transgenic plants environmental influence and social-economic-destruction of national seed system of important crops [3-5]. The possibility of appearance of any consequences depends on the scale and duration of using. Thus control of GMO using and circulation is performed in many world countries. Such a control supposes registration of new GMOs, post-registration control and food products labeling [6,7].

Rapeseed is important oil and feed crop. Rapeseed contains $38-50 \%$ of oil, $16-29 \%$ of protein, $6-7 \%$ of cellulose, $24-26 \%$ of nitrogen-free extractive matters. Rapeseed oil is used in food and medical production, agriculture and for bio-diesel obtaining. Rapeseed is a third oil crop after sunflower and soybean for plant areas and total production in Ukraine. The largest areas for this crop were in 2008 and amounted 1411,8 thousand hectares [8]. Programme of rapeseed development in Ukraine for 2008-2015 years supposes increasing of this sector in totally to $7 \%$, increasing of planted area to 2000 thousand hectares, obtaining 5600-6000 thousand tones of high-productive rapeseed with 28-30 centner/ha crop yield [9].

More than $90 \%$ non-processed rapeseed yield is implemented at external market. Thus Ukrainian exporters have a huge interest in it control for GMO content. Official data concerning rapeseed production is absent in Ukraine. But native rapeseed GMO testing during 2010-2014 which was conducted in laboratory of molecular-genetic researches of SE «Ukrmetrteststandard», showed the presence of genetic modified content.

Object of research was design of GM rapeseed detection method and development of native screening diagnostic system and monitoring of distribution of biotech rapeseed in Ukraine. 
Material and methods of research. Work was done at molecular-genetic laboratory of Scientificresearch center of products testing SE «Ukrmetrteststandard», which is accredited by National accreditation Agency according to ДСТУ ISO / IEC 17025-21.

We extracted DNA from standard reference non-and GM rapeseed of native selection. DNA was extracted by CTAB-precipitation method with iwn modifications. DNA concentration and purity was detected by A260/A280 and A260/A230 by «BioPhotometer AG 22331» (Eppendorf, Germany) [10].

For Real-Time PCR detection system for qualitative GM rapeseed detection TaqMan technology was used [11]. PCR amplification was done by iQCycler (BioRad, France) and CFX96 (BioRad, USA). Reaction mix with volume $20 \mu$ l contained $2 \mu$ l of DNA, $10 \mathrm{mM}$ Tris- $\mathrm{HCl}(\mathrm{pH} 8,3), 50 \mathrm{mM} \mathrm{KCl}, 2,5 \mathrm{mM}$ $\mathrm{MgCl} 2,0,2 \mathrm{mM}$ dNTP of mix, $10 \mathrm{pmol}$ of each primer, $5 \mathrm{pmol}$ of probe and $1 \mathrm{u}$ of Taq-polymerase (Thermo Scientific, Lithuania). Oligonucleotides were labeled by fluorescent dyes FAM, HEX, ROX, Cy5 and fluorescent quenchers BHQ1 and BHQ2. Temperature regime consisted of initial denaturation during $3 \mathrm{~min} 95^{\circ} \mathrm{C}$ and following 45 cycles: denaturation $-15 \mathrm{~s}$ 95으, primer annealing and synthesis $-40 \mathrm{~s}$ $60 \circ$. Fluorescent was measured after primer annealing stage and synthesis at each amplification cycle.

«Sigma-Aldrich» (USA), «Thermo Scientific» (Lithuania) and «Metabion» (Germany) reagents were used for design test-system. Sensitivity of designed test-system was detected with tenfold dilution of DNA of standard samples. Specificity was detected by testing of GM rapeseed, soybean and maize DNA $[12,13]$.

Results and discussion. GM-screening in food products and agricultural raw material is usually done by general regulator elements of genetic constructs such as 35 s promoter of cauliflower mosaic virus, CaMV and terminator NOS from Agrobacterium tumefaciens. But not in GM rapeseed case. CaMV virus, from which P35s was taken, affects uppermost Brassicaceae, rapeseed also belongs to it. Thus P35s presence in tested rapeseed samples can be results either of genetic constructs presence and of genetic material of natural virus. Detection only for tNOS is not effective. Almost 30 biotechnological rape lines are registered for today (Табл. ). Near third of them has tNOS sequences, and some lines are obtained by mutagenesis. This fact strictly limits screening analysis only for regulator elements. Thus design of another strategy of detection existing transgenic rapeseed lines appeared.

Monitoring of rapeseed on GMOs for years

\begin{tabular}{|c|c|c|c|c|c|}
\hline \multirow[t]{2}{*}{ Year } & \multirow[t]{2}{*}{$\begin{array}{l}\text { Number } \\
\text { the samples }\end{array}$} & \multirow[t]{2}{*}{$\begin{array}{c}\text { Number } \\
\text { samples rape }\end{array}$} & \multirow{2}{*}{$\begin{array}{c}\text { Number of } \\
\text { samples rape } \\
\text { GMO }\end{array}$} & \multicolumn{2}{|c|}{$\begin{array}{l}\text { Roundup Ready } \\
\text { (CP4 EPSPS) }\end{array}$} \\
\hline & & & & $\varnothing .9 \%$ & $>0.9 \%$ \\
\hline 2010 & 2570 & 54 & 13 & \multicolumn{2}{|c|}{10} \\
\hline 2011 & 1866 & 19 & 4 & \multicolumn{2}{|c|}{3} \\
\hline 2012 & 2001 & 76 & 7 & 3 & 4 \\
\hline 2013 & 1769 & 67 & 13 & 5 & 6 \\
\hline 2014 & 1609 & 112 & $24(21)$ & 13 & 11 \\
\hline Total & 9815 & 328 & 61 (19) & \multicolumn{2}{|c|}{55} \\
\hline
\end{tabular}

One of the widespread GMO-detective approaches is analysis for structural genes. In this case primer design is additional way to direct reaction specificity in a appropriate way. Primers must be specific to DNA sequence, which is located in different genetic elements, for the instance in a promoter-structural gene or in structural gene-terminator. Such a way of analysis detects rather less known GMOs, comparatively to detection for regulator elements, but such detection is more specific. There is detailed information concerning registered biotech crops lines, particularly rapeseed, in international electronic databases [14]. Performed comparative analysis of genetic constructs which were used for transgenic rapeseed lines creation, allowed detection the range of unique consequences, which are used as targets in PCR-analysis. Five sequences were selected totally. First is CP4 epsps from Agrobacterium tumefaciens CP4 stam ad from chloroplast transit peptide CTP2 from Arabidopsis thaliana and allows detect three GM rapeseed lines - GT73, GT200 (Roundup Ready ${ }^{\mathrm{TM}}$ ), MON88302 (Roundup Ready $2^{\mathrm{TM}}$ ), and hybrid combinations obtained from them (Table 1). Second sequence is located in range of P35s and posphinotricin $\mathrm{N}$-acetyltransferase gene from Streptomyces viridochromogenes (Pat) and allows detection three GM rapeseed lines - HCN10, HCN92 (Liberty Link ${ }^{\mathrm{TM}}$ ) and T45 (InVigor ${ }^{\mathrm{TM}}$ ). Third sequence is located in range of posphinotricin $\mathrm{N}$-acetyltransferase gene from Streptomyces hygroscopicus (Bar) and allows detection 16 biotechnological rape lines more. Last sequences belongs to 
thioesterase (bay TE) from Umbellularia californica and nitrilase genes (bxn) from Klebsiella pneumoniae and allows detection 23-18-17, 23-198 (Laurical ${ }^{\mathrm{TM}}$ ) and OXY-235 (Navigator ${ }^{\mathrm{TM}}$ ), lines accordingly [15].

Primers and probes for Real-Time PCR were design by Primer Express 3.0 (Applied Biosystems). Probes specific to CP4 epsps, Pat and Bay TE sequences were labeled by fluorescent dye ROX, probes to Bxn gene and tNOS were labeled by FAM gene, to Bar gene- by Cy5 dye and endogene control - by HEX. As endogene speciesspecific control rapeseed cruciferine gene (Cru) was used.

Optimization of amplification conditions was performed for primer annealing temperature, concentration of $\mathrm{MgCl}_{2}$, concentration and relation of primers and probes. Optimal temperature for selected primers effective work amounted $60 \stackrel{\circ}{\circ} \mathrm{C}$. $2,5 \mathrm{mM}$ concentration was the most effective among selected concentrations of $\mathrm{MgCl}_{2}(1,5 ; 2 ; 2,5$ and $3 \mathrm{mM})$. Performing reaction series with different primers and probes combinations in the range of 2 to $20 \mathrm{pmol}$ allowed minimal $C_{T}$ value and $\Delta R \mathrm{R}$ maximum value with constant matrix-target concentration. Optimal concentration value amounted 10 pmol for primers and 5 pmol for probes.

Effectiveness evaluation of test-system, in particular specificity, detection level, repeatability and reproducibility results was performing according to JRC, EU requirements with certified reference samples from IRMM, EU and from AOCS, USA. DNA of each standard and tested sample was extracted and analysed in two repeats. Experimental specificity detection showed no cross-reactions. Sensitivity level was about 20 DNA-target copies what satisfies requirements of ДСТУ ISO 21570:2008 [13].

Thereby our designed test-system "GM rapeseed-screening" allows identification most of GM rapeseed lines without their detail identification. This system is multiplex, because it allows performing three independent reactions in one tube and consists of three targets. The first PCR-mix allows to identify CP4 epsps, Bar and Cru genes. Second and third allows to identify Pat, tNOS, Cru and Bay TE, Bxn, Cru, respectively. The methodic of performing the measurements MBB 081/12-0751-11 for CP4epsps/Pat/Bar/P35S/tNOS DNA sequences identification was designed in 2011 and technical conditions TY Y 24.6-02568182-001:2011 for test-system design was received in 2012 [16,15].

Food products and agricultural raw material monitoring during 2010-2014 showed biotech rapeseed presence in Ukraine (table 1). Laboratory tested 9815 samples totally during this period. Most of it was food products. Agricultural raw material was presented by such crops as soybean, maize, rapeseed, wheat, rice and products of it processing. All tested samples had a native origin. We tested also rapeseed cake and oil, not only rapeseed. Total amount of tested rapeseed samples were 328 for the all period.

We tested 54 rapeseed samples and products of it processing in 2010. GM rapeseed was detected in 13 samples what amounts $24 \%$. Most of detected GMOs was presented by Roundup Ready tolerant rapeseed, because we detected positive signal for CP4 epsps gene.

There were not so many samples (1866) for testing at our laboratory during 2011, particularly rapeseed (19). GM content was detected in 4 rapeseed samples what amounts $21 \%$. In one of GMpositive sample Pat gene was detected, in remained three- CP4 epsps gene.

Since 2012 we designed the method of GM rapeseed quantitative detection for CP4 epsps gene. For this purpose we used standard GM rapeseed AOSC samples[17]. Quantitative detection is based on calculation of correlation between quantity of genetic modified DNA to total quantity of DNA of analyzed plant, in percentagewise. Thus for quantitative analysis we used calibration curve for standard samples, which contained 0,$1 ; 0,5 ; 1 ; 5$ and $10 \%$ of GT73 line rapeseed. For this purpose quantity of genetic modified material was normalized to quantity of plant material for $\Delta \mathrm{Ct}$ value $(\Delta \mathrm{Ct}=\mathrm{Ct} \mathrm{CP} 4 \mathrm{epsps}-\mathrm{Ct}$ $\mathrm{Cru})$. Calibration curve was made by values of $\Delta \mathrm{Ct}$ of standard samples. Calibration curve is a diagram of dependence of $\Delta \mathrm{Ct}$ from log of standards concentration. In relation to this curve we evaluated absolute values of tested samples for their $\Delta \mathrm{Ct}$ values.

We detected 76 rapeseed and products of it processing samples totally during 2012 , and only 7 (9\%) contained GMO. All seven samples showed positive signal for CP4 epsps gene. Quantitative analysis showed GM content more than $0,9 \%$ in 4 samples. 67 samples were tested in 2013 and 13 (19\%) contained GMO. Among them 2 samples showed positive signal for Pat gene, rest of the samples showed positive signal for CP4 epsps gene. Six CP4 epsps-positive samples contained GMO more than $0,9 \%$. More rape samples were tested during 2014 (112), from them $24(21 \%)$ contained GMO. All positive samples were Roundup Ready ${ }^{\mathrm{TM}}$ rape, 11 contained GMO more than $0,9 \%$.

Thus most detected GMOs contained CP4 epsp gene, and we can be aware of Roundup Ready ${ }^{\mathrm{TM}}$ rapeseed presence. Unfortunately monitoring of GM rapeseed distribution in all country is impossible because in many Ukrainian laboratories access to relevant information is strictly limited. 


\section{Conclusions.}

Methodological approach and Real-Time-PCR-based test-system for GM rapeseed detection were designed. Test-system detects all rapeseed transgenic lines without their detail identification. Designed test-system fulfills international standards requirements for PCR-analysis for qualitative and quantitative GMO detection in food products and raw materials. Test-sustem is adapted to most devices (Bio-Rad, Applied Biosystems, Corbett Research, Sintol, DNA-technology) in diagnostic laboratories of Ukraine.

Designed test-system was successfully used for GM rapeseed distribution monitoring in Ukraine. Data from 2010-2014 pp. shows Roundup Ready ${ }^{\mathrm{TM}}$ rapeseed presence, in quantity more than $0,9 \%$, in spite of ban for biotech crops breeding in Ukraine.

\section{Bibliography}

1. Clive James. Global Status of Commercialized Biotech/GM Crops: 2014 / ISAAA Brief №49. ISAAA: Ithaca, NY. - 2014. [Електронний ресурс]. - Режим доступу: http://www.isaaa.org/resources/publications/briefs/49/default.asp

2. Clive James. Global Status of Commercialized Biotech/GM Crops: 2013 / ISAAA Brief №46. ISAAA: Ithaca, NY. - 2013. [Електронний ресурс]. - Режим доступу: http://www.isaaa.org/resources/ publications/briefs/46/default.asp

3. Kartakhens'kyy protokol pro biobezpeku do Konventsiyi pro biolohichne riznomanittya [Elektronnyy resurs]. - Rezhym dostupu: http://www.biodiv.org/biosafety/

4. Yhnat'ev Y. Henetychesky modyfytsyrovannыe orhanyzmы у obespechenye biolohy-cheskoy bezopasnosty / Y. Yhnat'ev, Y. Trombytskyy, A. Lozan. - Benderы: Эkospektr. - 2007. - 60 s.

5. Carpenter J. Impact of GM crops on biodiversity / J. Carpenter // Nature Biotechnology. - 2010. Vol. 16(4). - P. 46-51.

6. Safety aspects of genetically modified foods of plant origin / Report of a Joint FAO/WHO Expert Consultation on Foods Derived from Biotechnology. - 2000. - 37 p.

7. Balasynovych B. HMO: vyklyky s'ohodennya ta dosvid pravovoho rehulyuvannya / B. Balasynovych, Yu. Yaroshevs'ka // Instytut ekonomichnykh doslidzhen' ta politychnykh konsul'tatsiy. - K. : Vydavnychyy dim "ADEF-Ukrayina", 2010. - $256 \mathrm{~s}$.

8. Roslynnytstvo Ukrayiny 2012. Statystychnyy zbirnyk. - K.: Derzhavnyy komitet statystyky Ukrayiny. $-2013 .-180 \mathrm{~s}$.

9. Prohrama rozvytku ripakivnytstva v Ukrayini na 2008-2015 rr. vid 21 lyutoho 2006r. [Elektronnyy resurs]. - Rezhym dostupu: http://minapk.kiev.ua/page/?7207

10. Metody vyyavlennya henetychno modyfikovanykh orhanizmiv i produktiv z yikhnim vmistom. Ekstrahuvannya nukleyinovoyi kysloty. I DSTU ISO 21571:2008. - Kyyiv: Derzhspozhyvstandart Ukrayiny. - 2009. $-31 \mathrm{~s}$.

11. PTsR v real'nom vremeny / D.V. Rebrykov, H.A. Samatov, D.Yu. Trofymov y dr.; pod redaktsyey D.V. Rebrykova. - M.: BYNOM. Laboratoryya znanyy. - 2009. - 223 s.

12. Metody vyyavlennya henetychno modyfikovanykh orhanizmiv i produktiv z yikhnim vmistom. Yakisni metody na osnovi analizuvannya nukleyinovoyi kysloty / DSTU ISO 21569:2008. - Kyyiv: Derzhspozhyvstandart Ukrayiny. - 2009. - 48 s.

13. Metody vyyavlennya henetychno modyfikovanykh orhanizmiv i produktiv z yikhnim vmistom. Kil'kisni metody na osnovi analizuvannya nukleyinovoyi kysloty. / DSTU ISO 21570:2008. - Kyyiv: Derzhspozhyvstandart Ukrayiny. - 2009. - 70 s.

14. The Center for Environmental Risk Assessment (CERA) [Електронний ресурс]. - Режим доступу: http://www.cera-gmc.org/GMCropDatabase

15. «Test-systemy dlya vyznachennya yakisnoho ta kil'kisnoho vmistu henetychno modyfikovanykh orhanizmiv (HMO) roslynnoho pokhodzhennya v kharchovykh produktakh. Tekhnichni umovy» / TU U 24.6-02568182-001:2011. - Kyyiv: DP «Ukrmetrtest-standart». - 2012. - $52 \mathrm{~s}$.

16. «Metodyka vыpolnenyya yzmerenyy DNK posledovatel'nostey (CP4epsps/PAT/ BAR/35S/NOS skrynynh) henetychesky modyfytsyrovannykh orhanyzmov $v$ pyshchevыkh, farmakolohycheskykh y kosmetycheskykh produktakh, pyshchevom sur'e rastytel'noho proyskhozhdenyya y kormakh metodom PTsR-RV» / MVV 081/12-0751-11. - Kyyiv: DP «Ukrmetrtest-standart». - 2011. - 14 s.17. Certified Reference Materials (CRM) AOCS [Електронний ресурc]. - Режим доступу: http://www.aocs.org/ LabServices/content.cfm?ItemNumber=19248 